\title{
Antimicrobial effect of Lagenaria siceraria (M ol.) Standley, against certain bacteria and fungal strains
}

\section{Y.P. Nagaraja*, K. N. G eetha and M. S. Vinay}

Department of Biotechnology, Nagarjuna College of Engineering and Technology, Mudugurki, Venkatagirikote post, Devanahalli Taluk, Bangalore - 562110 (Karnataka), INDIA

${ }^{*}$ Corresponding author. E-mail: Drnagaraja_yp@rediffmail.com

Abstract: This study was performed to evaluate the antibacterial and antifungal potency of Lagenaria siceraria (Mol.) Standley, commonly known as bottle gourd belonging to the family Cucurbitaceae. Petroleum Ether, Chloroform, Methanol, Absolute alcohol and Water showed a majority of the compound including Steroids, Alkaloids, Tannins, Flavonoids, Lactones and Carbohydrates. All the five extracts were prepared by using soxhlet apparatus and the extracts showed moderate to potent antimicrobial activity against the bacterial strains: Escherichia coli, Enterococcus faecalis, Klebsiella pneumonia, Salmonella typhi, Staphylococcus aureus and antifungal strains: such as Aspergillus flavus, Aspergillus oryzae and Trichoderma harzianum.

Keywords: Lagenaria siceraria, Antibacterial, Antifungal, Phytochemicals, Leaf extracts

\section{INTRODUCTION}

The use of plant extracts and phytochemicals both with known antimicrobial properties can be of great significance in therapeutic treatments (Shapoval et al., 1994). Many plants are used as medicines because of their antimicrobial nature, which are due to compounds synthesized in the secondary metabolism of the plant. These products are known by their active substances (Geethalakshmi et al., 2010). The demand on plant based therapeutics is increasing in both developing and developed countries due to growing recognition that they are natural products, easily biodegradable producing minimum environmental hazards, no side effects and easily available at affordable price. India is the largest producer of medicinal herbs and traditional practitioners of this country use more than 6000 medicinal plants in primary health care (Shariff et al., 2006).

Lagenaria siceraria (Mohl.) Standley fruit (Syn. L. vulgaris Ser., Cucurbita legenaria, Linn., L. leucantha Rusbey, belongs to the family Cucurbitaceae), commonly known as Bottle gourd is distributed in Africa, Asia and America. The first and foremost important use of bottle gourd was as a water carrier. Medicinally it is used as a purgative, an antidote for certain poisons and a cure for coughs (Uphof, 1959). An infusion of the seeds has been used to cure chills and for headaches, and juice from the leaves was taken against jaundice and to cure baldness (Moerman, 1998 and Deshponde et al., 2008). The present study was undertaken to evaluate the potentiality of aqueous and organic solvent extracts of L. siceraria against some medically important bacterial and fungal strains.

\section{MATERIALS AND METHODS}

Test plant material : The fresh plant material of the $L$. siceraria was collected from Hoskote forest ranges near Bangalore in Karnataka, India during February 2009.

Test organisms: To find out the antimicrobial activity of various extracts of $L$. siceraria, the different strains of pathogenic bacteria used are Escherichia coli ATCC25922, Enterococcus faecal is ATCC29212, Klebsiella pneumonia ATCC31488, Salmonella typhi ATCC6539, Staphylococcus aureus ATCC25923 and antifungal strains includes Aspergillus flavus ATCC32611, Aspergillus oryzae ATCC76080, Trichoder ma harzianum ATCC20476.

Extraction and phytochemical analysis: The surface of the leaves were washed in distilled water to remove the surface microflora and are then shade dried, pulverized by a mechanical grinder and passed through a $40 \mu \mathrm{m}$ mesh sieve to get the fine powder and stored in an airtight container. The dried powder $(50 \mathrm{~g})$ was extracted by soxhlet extraction method using different solvents namely, Petroleum Ether, Chloroform, Methanol, Absolute alcohol and Water sequentially. The solvents from various extracts were then concentrated in a rotavapour at reduced pressure below $40^{\circ} \mathrm{C}$ and the extract thus obtained was stored in airtight bottles at $4^{\circ} \mathrm{C}$ for further experiments.

Q ualitative tests for phytochemical analysis: The phytochemicals in the plants were investigated by performing standard qualitative tests for the presence of 
Table 1. Preliminary phytochemical screening of Lagenaria siceraria.

\begin{tabular}{lcc}
\hline SI.No. & Tests & Occurrence \\
\hline 1. & Steroids & + \\
2. & Alkaloids & + \\
3. & Tannins & - \\
4. & Flavonoids & + \\
5. & Lactones & + \\
6. & Carbohydrates & + \\
\hline
\end{tabular}

alkaloids, flavanoids, saponins, tannins, terpenoids, steroids, lactones and carbohydrates were evaluated according to the methods described by Edeoga et al. (2005). Antimicrobial activity assay

Disc diffusion test: The in vitro antimicrobial activity of the sample solution was done by disc diffusion method (Bauer et al., 1966). Plates were prepared by pouring 20 $\mathrm{ml}$ of sterile nutrient agar media (Hi media) into sterile petridishes and were inoculated with a loopful broth culture of each organism. Sterile whatmann filter paper discs (6 mm diameter) impregnated with $20 \mathrm{ml}$ quantity of dimethyl sulfoxide solution of various extracts was air dried and placed on the agar plates. The plates were incubated at $37^{\circ} \mathrm{C}$ for $24 \mathrm{~h}$. control studied with Chloramphenicol and Nystatin $30 \mathrm{mg}$ were used as standards for bacteria and fungi, the solvent DMSO control was concurrently (Umadevi et al., 2003). The growth inhibition of each microbial strain was calculated as the percentage of inhibition of radial growth relative to the control. The plates were used in triplicate for each treatment. The relative growth inhibition of treatment compared to control was calculated by percentage, using the following formula:

Radial growth of treatment (mm)

Inhibition $\%=1 \frac{\text { Radial growth of control (mm) }}{\mathrm{m} \text { ) }} \times 100$

M inimal inhibitory concentration (MIC) assay: Minimum Inhibitory Concentration assay was performed by dilution method as described by National Committee for Clinical Laboratory Standards (NCCLS, 1993) using Muller Hinton agar medium (Hi-media). All the test extracts including standard was taken in discs. The discs were dipped in extracts having the concentrations of 0.0625 , $0.125,0.25$ and $0.5 \mathrm{mg} / 10^{3}$. The plates were incubated at $37^{\circ} \mathrm{C}$ for $24 \mathrm{~h}$. The assay was repeated twice and the antimicrobial potency of different microbial strains was determined by observing the inhibitory zone of microbial strains. The lowest concentration showing no inhibitory zone was considered as the MIC.

\section{RESULTS}

Extraction yield and phytochemical estimation: The results of phytochemical analysis of petroleum ether, chloroform, methanol, absolute alcohol and water extract has revealed the positive results for alkaloids, steroids, flavonoids, lactones and carbohydrates and negative results for tannins. The phytochemical analysis of water and ethanol extract has shown the presence of saponins and terpenoids respectively (Table 1).

The results of antibacterial activity of $L$. siceraria extract in vitro are given in Tables 2 and 3.It was observed that, the plant is possessing more activity against Escherichia coli 14.2 $\pm 3.77,13.4 \pm 3.13,14.4 \pm 2.88,9.8 \pm 1.48$, Enterococcus faecalis $13.6 \pm 3.21,12.4 \pm 2.88,17.0 \pm 4.00$, $8.0 \pm 1.41$, and Staphylococcus aureus $14.6 \pm 2.61$, $13.0 \pm 2.00,13.8 \pm 3.03,6.6 \pm 2.07$ in petroleum ether, chloroform, methanol and water extracts respectively, whereas in case of K lebsiella pneumonia $11.4 \pm 1.34$,

$04.6 \pm 6.39,11.8 \pm 1.79,7.0 \pm 2.24$ and Salmonella typhi $15.2 \pm 4.60,04.8 \pm 6.72,11.6 \pm 2.19,5.6 \pm 3.21$, the growth of inhibition was less.

In the case of antifungal activity, the growth of inhibition was comparatively more with respect to Aspergillus flavus $13.2 \pm 2.28,13.4 \pm 2.19,10.8 \pm 1.10,5.0 \pm 3.81$ Aspergillus oryzae $12.8 \pm 3.35,13.0 \pm 1.00,10.4 \pm 0.89$, $3.6 \pm 3.36$, but the growth of inhibition was less in case of Trichoderma harzianum $00.0 \pm 0.00,14.2 \pm 2.28,11.2 \pm 1.79$, 4.2 \pm 3.03 .

Thus the different solvent extracts have showed different results with different microorganisms. The petroleum ether extracts has showed MIC at $0.25 \times 10^{3} \mathrm{mg} / \mathrm{ml}$ in bacterial strains whereas in fungi MIC was shown positive for A. oryzae. The chloroform extract in bacteria

Table 2. Antimicrobial activity of various extracts of L. siceraria on different microbes.

\begin{tabular}{|c|c|c|c|c|}
\hline & Petrol eum ether extract & Chlorotorm extract & M ethanol extract & W ater extract \\
\hline Microorganisms & \multicolumn{4}{|c|}{ 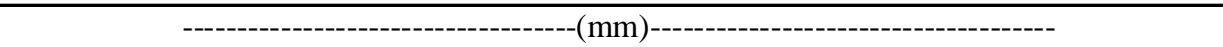 } \\
\hline \multicolumn{5}{|l|}{ Bacterial Strains } \\
\hline Escherichia coli & $14.2 \pm 3.77$ & $13.4 \pm 3.13$ & $14.4 \pm 2.88$ & $9.8 \pm 1.48$ \\
\hline E nterococcus faecalis & $13.6 \pm 3.21$ & $12.4 \pm 2.88$ & $17.0 \pm 4.00$ & $8.0 \pm 1.41$ \\
\hline Klebsiella pneumonia & $11.4 \pm 1.34$ & $04.6 \pm 6.39$ & $11.8 \pm 1.79$ & $7.0 \pm 2.24$ \\
\hline Salmonella typhi & $15.2 \pm 4.60$ & $04.8 \pm 6.72$ & $11.6 \pm 2.19$ & $5.6 \pm 3.21$ \\
\hline Staphylococcus aureus & $14.6 \pm 2.61$ & $13.0 \pm 2.00$ & $13.8 \pm 3.03$ & $6.6 \pm 2.07$ \\
\hline \multicolumn{5}{|l|}{ Fungal Strains } \\
\hline Aspergillus flavus & $13.2 \pm 2.28$ & $13.4 \pm 2.19$ & $10.8 \pm 1.10$ & $5.0 \pm 3.81$ \\
\hline Aspergillus oryzae & $12.8 \pm 3.35$ & $13.0 \pm 1.00$ & $10.4 \pm 0.89$ & $3.6 \pm 3.36$ \\
\hline Trichoderma harzianum & $00.0 \pm 0.00$ & $14.2 \pm 2.28$ & $11.2 \pm 1.79$ & $4.2 \pm 3.03$ \\
\hline
\end{tabular}

The values are mean $\pm \mathrm{S}$. D. of zone of inhibition 
Table 3. Antimicrobial activity of various extracts of L. siceraria on different microbes.

\begin{tabular}{|c|c|c|c|c|}
\hline & Petroleum ether extract & Chloroform extract & Alcohol extract & Water extract \\
\hline Micr oorganisms & - & (mg) & - & - 2 \\
\hline \multicolumn{5}{|l|}{ Bacterial Strains } \\
\hline Escherichia coli & 0.43 & 0.66 & 0.25 & 0.25 \\
\hline E nterococcus faecalis & 0.66 & 0.25 & 0.66 & 0.25 \\
\hline Klebsiella pneumonia & 0.25 & 0.8 & 0.43 & 0.25 \\
\hline Salmonella typhi & 0.43 & 0.8 & 0.25 & 0.25 \\
\hline Staphylococcus aureus & 0.25 & 0.43 & 0.43 & 0.25 \\
\hline \multicolumn{5}{|l|}{ Fungal Strains } \\
\hline Aspergillus flavus & 0.43 & 0.66 & 0.11 & 0.8 \\
\hline Aspergillus oryzae & 0.11 & 0.11 & 0.66 & 0.8 \\
\hline Trichoderma harzianum & 0.8 & 0.11 & 0.11 & 0.8 \\
\hline
\end{tabular}

The values are mean \pm S. D. of MIC.

showed MIC in E. coli, E. faecalis and S. aureus at 0.25 $\mathrm{x} 10^{3} \mathrm{mg} / \mathrm{ml}$ and in case of fungi, the extract was able to show the MIC at $0.11 \times 10^{3} \mathrm{mg} / \mathrm{ml}$ and $0.25 \times 10^{3} \mathrm{mg} / \mathrm{ml}$. The methanol extract has showed MIC in $0.25 \times 10^{3} \mathrm{mg} / \mathrm{ml}$ and $0.43 \times 10^{3} \mathrm{mg} / \mathrm{ml}$ in bacterial strains and $0.11 \times 10^{3} \mathrm{mg} /$ $\mathrm{ml}$ and $0.66 \times 10^{3} \mathrm{mg} / \mathrm{ml}$ in the case of fungi (Table 3).

\section{DISCUSSION}

The results obtained in this study showed the presence of antimicrobial activity of $L$. siceraria, in the preliminary screening of antimicrobial activity using disc diffusion method. The antibacterial activity of $L$. siceraria water extract was lower than the organic solvent extracts however the results are concurrent with the earlier report done by Tolulope (2007) in Hibiscus sabdariffa against S. aureus, E. coli and K. pneumoniae. Ghosh et al. (2008) have also used similar bacterial sources in their investigation. It includes, E scherichia coli, Enterococcus faecalis, Klebsiella pneumonia, Salmonella typhi and Staphylococcus aureus and got more zone of inhibition in the methanol extract. However, in the present study also it is revealed that the extracts of petroleum ether, chloroform and methanol have showed more zone of inhibition than the water extract and it is also suggesting that, the inhibition is more in E. coli, E. faecalis and S. aureus but it was comparatively less in case of $K$. pneumonia and S. typhi.

The antifungal property of the plant species has been done by using three different strains amongst $A$. flavus which showed more zone of inhibition than the other two strains. This is due to the chemical property of the extract which inhibited the growth of the fungi. Similar types of results were also observed by Cichewicz and Thorpe (1996). Many plants have been used to screen the antimicrobial property because of their antimicrobial traits, which are due to chemical compounds sythesised in their secondary metabolism of the plant such as alkaloids (O. T. A. Plants, 1985 and Omulokoli et al., 1997); flavonoids (Batista et al., 1994). Incase of petroleum ether extract, the MIC was found to be more at $0.25 \times 10^{3} \mathrm{mg} / \mathrm{ml}$. Even in case of fungi A. oryzae showed MIC at $0.11 \times 10^{3} \mathrm{mg} /$ $\mathrm{ml}$ and A. flavus at $0.25 \times 10^{3} \mathrm{mg} / \mathrm{ml}$. The results are similar to the report mentioned by the earlier workers like Geethalakshmi et al., (2010). It was concluded that, the most susceptible bacterial was $E$. faecalis while most resistant was $S$. typhi and in case of fungi the most susceptible fungal strain was $A$. flavus while most resistant was $T$. harzianum.

\section{ACKNOWLEDGEMENTS}

The authors wish to thank the Principal, Director and Management of Nagarjuna College of Engineering and Technology for providing necessary facilities to carryout the research work.

\section{REFERENCES}

Batista, O., Duarte,A., Nascimento, J. and Simones, M.F. (1994). Structure and antimicrobial activity of diterpenes from the roots of Plectranthus hereroensis. J . of Nat. Product. 57: 858-861.

Chopra. R. N., Nayar. S. L. and Chopra, I. C. (1986). G lossary of Indian Medicinal Plants (Including the Supplement). Council of Scientific and Industrial Research, New Delhi.

Cichewicz, R.H. and P.A. Thorpe (1996). the antimicrobial properties of the chile pepers (Copsicum species) and their uses in Mayan Medicine. J. Ethanopharmacol., 52: 61-70.

Decker-Walters, D.S., Wilkins-Ellert, M., Chung, S.-M. and Staub, J.E. (2004). Discovery and genetic assessment of wild bottle gourd [Lagenaria siceraria (Mol.) Standley, Cucurbitaceae] from Zimbabwe. E conomic B otany, 58: 501508.

Deshponde, J.R., A.A. Choudhari, M.R.Mishra, V.S. Meghre,S.G.Wadodkar and A. K. Dorle (2008). Beneficial effects of Legenaria si cer aria (Mol.) Standley fruit epicarp in animal models. Ind. J . of Exptl. Biol. 46: 234-242.

Dwivedi, S. K. and Singh, K. P. (1998).Fungitoxicity of some higher plant products against M acrophomina phaseolina (Tassi) Goid. Flavour and Fragrance J ounal, 13: 397-399.

Edeoga H.O., D.E. Okwu and B.O. Mbaebie (2005). Phytochemical constituents of some Nigerian medicinal plants. Afr. J . Biotechnol., 4: 685-688.

Facciola. S. (1990). Cornucopia - A Source Book of Edible Plants. Kampong Publications ISBN 0-9628087-0-9 Excellent. Contains a very wide range of conventional and unconventional food plants (including tropical) and where 
they can be obtained (mainly N. American nurseries but also research institutes and a lot of other nurseries from around the world.

Geethalakshmi, R., D.V.L. Sarada and Marimuthu, P. (2010). Evaluation of Antioxidant potentials of Trianthema decandra L. Asian J. of Biotechnology. 2 (4): 225-231.

Ghosh, A., Das, B.K., Chatterjee, S. K. and Chandra, G. (2008). Antibacterial potentiality and phytochemical analysis of mature leaves of polyalthia longifolia (Magnoliales: Annonaceae). The south pacific J . of Nat. Sci ., 26: 68-72.

Moerman, D. (1998). Native American E thnobotany Timber Press. Oregon. ISBN 0-88192-453-9. Very comprehensive but terse guide to the native uses of plants. Excellent bibliography, fully referenced to each plant, giving a pathway to further information. Not for the casual reader.

National Committee for Clinical Laboratory standards (1993). performance standards for antimicrobial disc susceptibility tests. Approved standard NCCLS Publications M2-A5. Villanova, PA, USA.

Omulokoli, E., Khan, B. and Chhabra, S.C. (1997). Antiplasmodial activity of four Kenyan medicinal plants. J. of Ethnopharmacology. 56: 133-137.

OTA Plants (1985). The Potentials for Extracting Protein, Medicines, and OtherUseful Chemicals-Workshop Proceedings (Washington, D.C. :U.S. Congress, Office of Technology Assessment, OTA-BP-F-23, September. 1983).

Shapoval, E.E.S; Silveria, S.M. Miranda, M.L. Alice, C.B. and Henriques, A.T. (1994). Evaluation of some pharmacological activities of Eugenia uniflora. J . of Ethanopharmacol. 44; 136-142.

Sheriff, N., Sudarshana, M.S., Umesha, S. and Prasad, P. (2006). Antimicrobial activity of Rauvolfia tetra phyla and Physalis minima leaf and callus extracts. African Journal of Biotechnology 5: 946-950.

Siddiqui, S, Verma, A., Rather A.A., Jabeen, F. and Mukesh K. Meghvansi (2009). Preliminary phytochemical analysis of some important medicinal and aromatic plants. Ad.in Biol. Res., 3 (5-6): 188-195.

Tolulope, O. M. (2007). Cytotoxicity and antibacterial activity of Methanolic extract of Hibiscus sadbariffa. J . of Med. Plants. Res., 1: 9-13.

Umadevi, S., G.P. Mohanta, V.Chelladurai, P.K. Mann and R. Manavalan (2003). Antibacterial and antifungal activity of Andrographis echiodes. I. Nat. Remedies, 3: 185-188.

Uphof, J. C. and Th. Weinheim (1959). An excellent and very comprehensive guide but it only gives very short descriptions of the uses without any details of how to utilize the plants. Not for the casual reader. Dictionary of E conomic plants.

Velazquez, E., H.A. Tournier, P. Mordujovich de Bushiazzo, G. Ssvedra and G.R. Schinella (2003). Antioxidant activity of Paraguayans plant extracts. Fitoter apia, 74:91-97.

Warrier P.K., Nambiar, V. P. K and Ramnkutty, C. (1995), Legenaria siceraria (Mol.) Standley, in indian medicinal plants. Vol. 3, 292. Orient Longman Limited, Madras, India Yoganarasimha SN. 1996. Medicinal Plants of India. Vol. I Interline Publishing Pvt., Lt., Bangalore, India. 